\title{
Fourier Transform Infrared Spectroscopic Analysis of Medicinal Plant (Bhringaraj) from the Duvva Village West Godavari District, Andhra Pradesh, India.
}

\author{
P. Saritha ${ }^{1}$ N. Gandhi ${ }^{2}$ and D. Shirisha ${ }^{3}$ \\ ${ }^{1}$ Department of H\&S, CVR College of Engineering, Hyderabad, India \\ 2, 3 Jawaharlal Nehru Institute of Advanced Studies (JNIAS), Hyderabad, India \\ Email: perumandla.saritha@gmail.com
}

\begin{abstract}
The main objective of the study is to determine the important features exhibited by FTIR. Dried leaves of Bhringaraj, a medicinal plant used in Ayurveda were selected for study. The vibrational assignments, intensities and wave numbers were obtained by absorption spectra. Various functional groups and chemical constituents were identified. This article gives an insight about the importance of herbal analysis and gives a platform for using these medicinal plants for developing wastewater treatment technology and for improving the quality of drinking water.
\end{abstract}

Index terms- Fourier Transform Infrared Spectroscopic (FTIR), Bhringaraj, water treatment technology.

\section{INTRODUCTION}

Medicinal plants are a group of plants that can be used as a drug or therapeutic agent or active ingredient of a medical preparation. Plants form a basis of traditional medicine practices that have originated from historic times. Plants are used as drugs and they are found in arthava veda which is the basis of Ayurvedic medicine (dating back to 2000BCE) the clay tablets in Mesopotamia (1700BCE) and Eber Paprus in Egypt (1550BCE). The demand for plant-based medicines is increasing because they do not have adverse effects, and they are rich source of bioactive ingredients, which show Pharmacological activities. In the present study, FTIR is used to identify the different functional groups present in the leaf powder of Bhringaraj. FTIR has become a versatile tool for identification, characterization and detection of biomolecules [1, 2]. High sensitivity of vibrational spectra helps in identifying biological molecules such as water, proteins, nucleic acid, carbohydrates etc [3]. FTIR peaks are relatively narrow and in many cases can be associated with a vibration of a particular chemical bond (or a single functional group).

\section{EXPERIMENTAL METHOD \& MATERIALS}

\section{Selection of Bhringaraj leaves}

The leaves of medicinal plant Bhringaraj were selected for the FTIR analysis were collected from the agriculture lands of Duvva Village, West Godavari District, Andhra Pradesh. The leaves were taxonomically authenticated.
Bhringraj in Ayurveda practitioners is commonly known as false daisy and it belongs to the family of Asteraceae, Botanical Name - Eclipta Alba. It is an erect, prostrate, branched roughly hairy herb grows commonly in moist places all over the world, as a weed. Phytochemical studies on Eclipta revealed the presence of Alkaloids like ecliptine and nicotine and bioactive steroidal alkaloids verazine dehydro verazine eclipatalbine [7]. Dried leaves have been reported to contain coumarins like wedelolactone and its derivatives [8], demethylwedelolactone, isodemethylwedelolactone and strycholactone [9], many hydrocarbons like ecliptal [10] d-formyl terthienyl [11]. Six new Oleanane triterpene, Glycosides, Eclalbasaponins I-IV are reported [12]. Many types of sterols and flavonoids are present in the bhringraj [13].

FTIR is used for identification of biomolecules [4-6, 24] the chemical constituent's in bhringaraj are known for its anticancer, antileprotic, analgesic, antioxidant, antiviral, antihaemorrhagic, antibacterial,

antimyotoxic, antihepatotoxic, spasmogenic, hypotensive and ovicidal properties.

Bhringaraj is used extensively by Ayurvedic practitioners, for treatment of Snakebites [14, 15], Scorpion stings [16]. It has anti-inflammatory [17] Bronchodilator activity $[18,19]$ Nootropic activity [20] and it is used to treat Ranikhet disease [21], Salmonella epidermidis and salmonella typhimurium infections [22], used for hair growth [23, 24] treating skin diseases and eye infections. Due to its anti-inflammatory properties, anti oxidant activity, anti cancer activity [25] and anti hyper lipidemic activity [26] the herb is also used for treating hyperacidity. Bhringaraj is the main herb for the hair care and cirrhosis in Ayurveda. It is believed to maintain and rejuvenate hair, teeth, bones, memory, sight, hearing, kidneys and liver.

Healthy plants and fresh leaves were collected. These leaves were air dried and shade dried at room temperature in clean environment to avoid contamination and powdered in a domestic grinder. The powdered sample is stored in air tight glass bottle at room temperature for further analysis. 


\section{INSTRUMENTAION}

\section{Spectro-Chemical Analysis}

The compact light weight Agilent Cary 630 FTIR connected to a sophisticated computer was used to record FTIR spectra of bhringaraj leaves in the spectral range of $4000-400 \mathrm{~cm}^{-1}$ at room temperature.

\section{RESULTS AND DISCUSSION}

FTIR spectrum of Bhringaraj was used to identify the functional groups of active components based on the peak value in the region $4000-400 \mathrm{~cm}^{-1}$ of infrared radiation. FTIR spectra of leaves of Bhringaraj were represented in Fig.1

This study has been undertaken with a view of identifying the functional groups present in the Bhringaraj leaves and to understand the significance of bioactive constituents present in it. The FTIR represented in Fig. 1 is of complex nature and it indicates the various chemical constituents and chemical structures in the biomolecules given in Table -1, Scheme-1. The FTIR spectra show many absorption bands, the presence of hydroxyl groups in the biomolecule absorbed at $3852.93 \mathrm{~cm}^{-1}, 3447.12 \mathrm{~cm}^{-1}$ and $3107.03 \mathrm{~cm}^{-1}$. The peak at $3852.93 \mathrm{~cm}^{-1}$ represents $\mathrm{OH}$ stretching of hydroxyl groups in phenols [22]. The peak at $3447.10 \mathrm{~cm}^{-1}$ is due to $\mathrm{OH}$ stretching. The absorption peaks at $2918 \mathrm{~cm}^{-1}$ and $2850 \mathrm{~cm}^{-1}$ represents asymmetric stretching of $\mathrm{CH}_{2}$ groups and symmetric stretching of $\mathrm{CH}_{3}$ groups indicating the presence of chlorophyll in biomolecule [24-29]. The peak at $2202 \mathrm{~cm}^{-1}$ may be due chain containing carbon double bonded with nitrogen which is termed as nitrile group [30\&31]. The band at $2096 \mathrm{~cm}^{-1}$ represents azide group [31]. IR spectral peaks at $1445 \mathrm{~cm}^{-1}$ and $1316.650 \mathrm{~cm}^{-1}$ exhibits a high molecular coupling and this region is very complex [26] involving several modes of vibration of lignin and carbohydrates. A band around $1450 \mathrm{~cm}^{-1}$ is reported to be deformation of lignin $\mathrm{CH}_{2}$ and $\mathrm{CH}_{3}$ which was reported previously. The absorption bands at $1100-1000 \mathrm{~cm}^{-1}$ is the finger print region indicating several modes such as $\mathrm{C}-\mathrm{H}$ deformations or $\mathrm{C}-\mathrm{O}$ or $\mathrm{C}-\mathrm{C}$ stretching pertaining to carbohydrates. Carbohydrates in the leaves are the major constituents of these absorption bands [32-35].<smiles>COc1cc(O)c2c(c1)oc(=O)c1c3cc(O)c(O)cc3oc21</smiles>

Wedelolactone

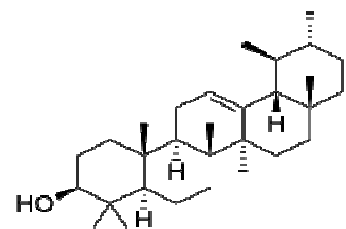

$\alpha$-amyrin<smiles>CC(O)=CC(O)C=C(OCC=CC(O)C1OCC(O)C(O)C(O)C1O)c1ccc(O)c(O)c1</smiles>

Luteolin 7-O-glucoside

\section{CONCLUSIONS}

Water plays a vital role in the development and public health of population in every part of the world. The methodology for the purification of water remains expensive in developing countries. Many water treatment processes use alum and chlorine where Alum causes alizimers disease and pathogenic microbes are resistant to chlorine.

This study has been of preliminary nature with the objective of establishing the use of medicinal plants for water and waste water treatment. To improvise the water quality and to control the water pollution the medicinal plant bhringaraj can be used which contains many chemical components which are confirmed by FTIR in this paper. This bhringaraj medicinal plant has capacity to remove the suspended particles, heavy metals and fluoride from water and waste water by coagulation and adsorption thus increase the quality of water. The sludge which is produce during the treatment is less toxic. Further work and application of bhringaraj and other medicinal plants are in progress.

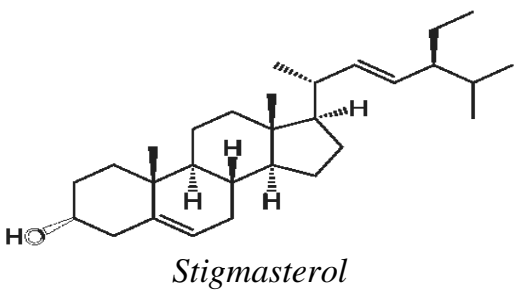<smiles>O=c1cc(-c2ccc(O)cc2)oc2cc(O)cc(O)c12</smiles> 
Scheme - 1 Structures of Chemical Componetnts Present in Bhringaraj Medical Plant

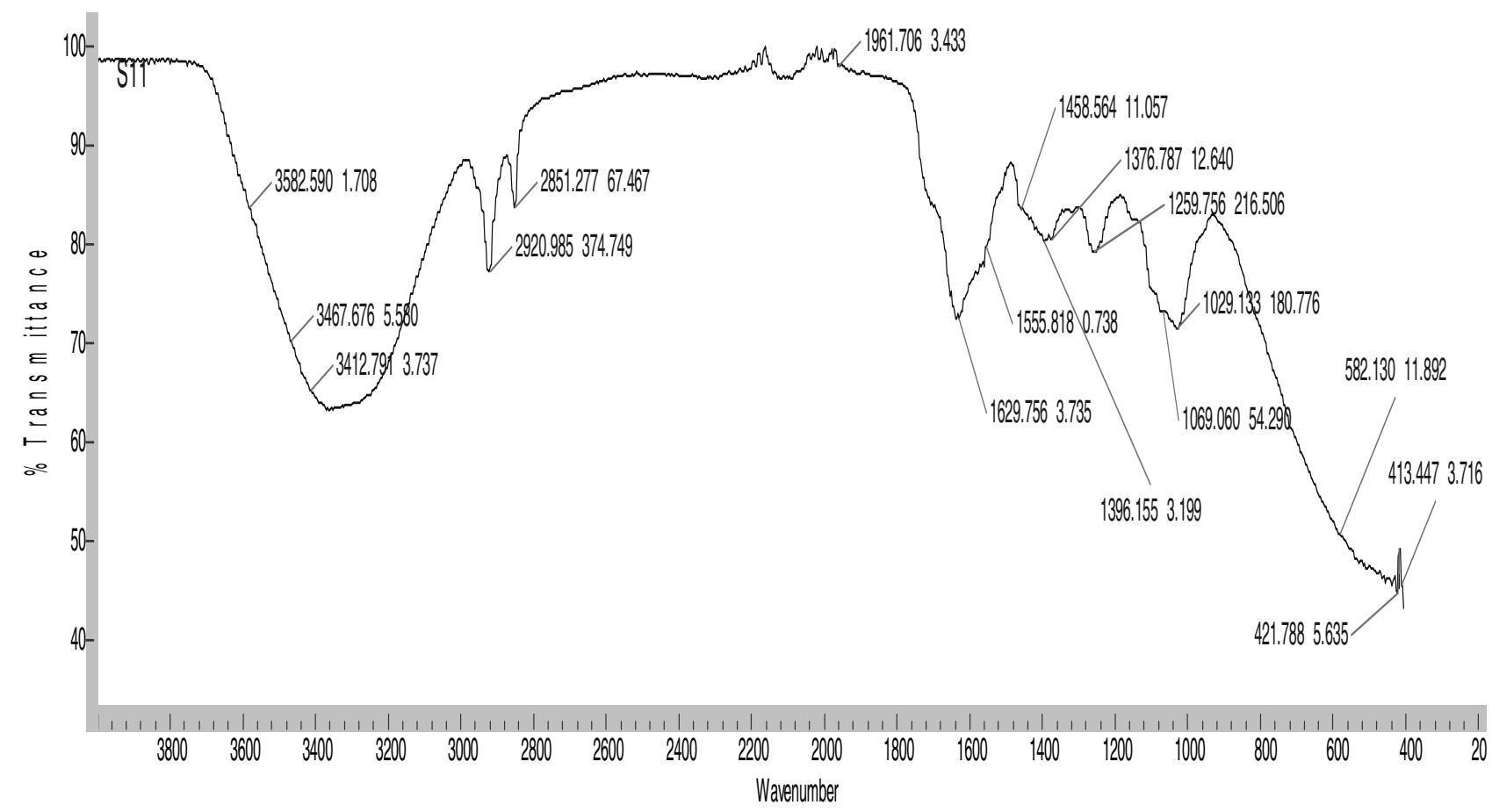

Figure 1. FTIR of Bhringaraj medicinal plant

TABLE -I

CHEMICAL COMPOSITION OF BHRINGARAJ PLANT LEAVES (ECLIPTA ALBA)

\begin{tabular}{|c|c|c|c|c|c|c|}
\hline $\begin{array}{c}S . N \\
o\end{array}$ & $\begin{array}{l}\text { Chemical } \\
\text { constituents }\end{array}$ & $\begin{array}{l}\text { Pharmacological } \\
\text { acticity }\end{array}$ & Formula & $\begin{array}{l}\text { Molecular } \\
\text { weight } \\
\text { (g/mol) }\end{array}$ & Iupac name & Other names \\
\hline 1 & Wedelolactone & $\begin{array}{l}\text { Anti-hepatotoxic, } \\
\text { Antibacterial, } \\
\text { Trypsin inhibitor, } \\
\text { Antivenom }\end{array}$ & $\mathrm{C}_{16} \mathrm{H}_{10} \mathrm{O}_{7}$ & 314.24 & $\begin{array}{l}\text { 1,8,9-trihydroxy-3-methoxy-6H- } \\
\text { [1]benzofuro[3,2-c]chromen-6-one }\end{array}$ & \\
\hline 2 & $\begin{array}{l}\text { Demethyl } \\
\text { wedelolactone }\end{array}$ & $\begin{array}{l}\text { Antihepatotoxic, } \\
\text { Antihaemorrhage, } \\
\text { Antivenom, } \\
\text { Dye (cosmetic) }\end{array}$ & & & & \\
\hline 3 & Apigenin & $\begin{array}{l}\text { Anti-cancer, compound, } \\
\text { Anti-inflammatory, } \\
\text { flavonoids, Dye }\end{array}$ & $\mathrm{C}_{15} \mathrm{H}_{10} \mathrm{O}_{5}$ & 270.24 & $\begin{array}{l}\text { 5,7-Dihydroxy-2-(4- } \\
\text { hydroxyphenyl)-4H-1-benzopyran- } \\
\text { 4-one }\end{array}$ & $\begin{array}{l}\text { 4',5,7-Trihydroxyflavone } \\
\text { Apigenine, Chamomile, } \\
\text { Apigenol,Spigenin,Versu } \\
\text { lin, }\end{array}$ \\
\hline 4 & $\begin{array}{l}\text { Leutolin7-O- } \\
\text { gluoside }\end{array}$ & $\begin{array}{l}\text { Antioxidant activity, } \\
\text { Antimicrobial }\end{array}$ & $\mathrm{C}_{21} \mathrm{H}_{20} \mathrm{O}_{11}$ & 448.37 & $\begin{array}{l}\text { 2-(3,4-dihydroxyphenyl)-5- } \\
\text { hydroxy-7 [(2S,3R,4S,5S,6R)-3,4,5- } \\
\text { trihydroxy-6-(hydroxymethyl)oxan- } \\
\text { 2-yl]oxychromen-4-one }\end{array}$ & $\begin{array}{l}\text { Glucoluteolin, } \\
\text { Luteoloside, Cinaroside } \\
\text { 7-Glucoluteolin } \\
\text { 7-Glucosylluteolin } \\
\text { Luteolin-7-glucoside } \\
\text { Luteolin-7-O-glucoside }\end{array}$ \\
\hline 5 & Stigmasterol & $\begin{array}{l}\text { Antioxidant, } \\
\text { Hypoglycemic }\end{array}$ & $\mathrm{C}_{29} \mathrm{H}_{48} \mathrm{O}$ & 412.6908 & $\begin{array}{l}(3 S, 8 S, 9 S, 10 R, 13 R, 14 S, 17 R)-17- \\
{[(E, 2 R, 5 S)-5 \text {-ethyl-6-methylhept-3- }} \\
\text { en-2-yl]-10,13-dimethyl- } \\
2,3,4,7,8,9,11,12,14,15,16,17- \\
\text { dodecahydro- } 1 H \text { - } \\
\text { cyclopenta[a]phenanthren-3-ol }\end{array}$ & Stigmasterin \\
\hline
\end{tabular}




\section{REFERENCES}

[1] Komal.J, A.G. Kumar, Devi prasad, Identification and Comparison of bio molecules in medicinal plants J.Biophysics 2011 21(1), 63-71.

[2] FTIR spectroscopy for identification of organisms, Clinical Microbiology Newsletter 2000, 22(8), 57-61.

[3] R. Dukor vibrational spectroscopy in detection of cancer, in hand book of vibrational spectroscopy vol. 5, edited by J.A. Chalmers, P. GRIFFITHS, Biomedical Applications pp. 3335-3361, 2002.

[4] Kang G.S etal., Chemical Bond structure of a C-F films with a low dielectric constant deposited by using $\mathrm{CH} 4 / \mathrm{CF} 4$ ICPCVD, Journal of Korean Physical society 42(5), 676681, 2003.

[5] Hofman, Pasiexzn, Wachowski speciation of functional groups formed on the surface of carbaneous materials Journal of Physics IV France 137, 287-290.

[6] Zanyer, Movassaghia, Shaaz, Rehman Fourior transform infrared spectroscopy of Biological tissues. Applied spectroscopy reviews 43, 134-179, 2008.

[7] Abdel Kadar etal.DNA damaging steroidal alkaloids from Eclipta alba, Journal of natural products 61, 1202-1268, 1998.

[8] Bhargava K. Krishnaswamy N, Seshadri T., Isolation of demethyl wedelolactone and it's glucosidal from Eclipta alba Indian Journal of Chemistry 8, 664-665, 1970.

[9] Zhang JS, Guo QM. 2001. Studies on the chemical constituents of Eclipta prostrata (L). Yao-Xue-Xue-Bao. 36, 34-37.

[10] Das.B, ChakravarthyA.K., Ecliptal a new terthienyl aldehyde from Eclipta alba Indian Journal of Chemistry 30, 1052-1053, 1991.

[11] Zhang M, Chen YY, Di XH, Liu M. 1997.Isolation and identification of ecliptasaponin D from Eclipta alba (L.) Hassk. Yao Xue Xue Bao. 32, 633-634.

[12] Upadyay R.K. Pandey M.B., Jha R.N., Pandey V.B, 2001, Eclalbatin, a triterepene saponin from Eclipta alba. Journal of Asian natural product research 3, 213-217, 2001.

[13] Yahara S. Ning. D, Teshihiro N, 2006, Six new oleanene triterpene glycosides, eclalba saponins I-IV isolated from Eclipta alba (1) Husk, Chemical and Pharma ceutical Bulletin 42, 1336-1338, 2006.

[14] Singh .P naturally occurring thiophene derivatives from Eclipta species Bioactive Molecules (7) 179-186, 1988.

[15] Anonymous 1993 Medicinal plants of Nepal Dept. of Medicinal plants, Nepal.

[16] A Valuable Medicinal herb, International IJCPR Nov. 2011-January 2012; 2(4); 188-197.

[17] Leal L.K,Ferreir, Bezerra GA, Matos FJ,Viana GS. 2000 Antinociceptive, Anti-Inflammatory and bronchodilator activities of Brazilian medicinal plants containing coumarin a comparative study Ethnopharmacology 70, 151-159.

[18] Arunachalam G, Subramanian N, Pazhani GP, Ravichandran V.2009. Anti-inflammatory activity of methanolic extract of Eclipta prostrata L. (Astearaceae). African Journal of Pharmacy and Pharmacology. 3, 97100.

[19] ThakurV.D, MeS. A. Neuropharmacological profile of Eclipta alba [L.] Hassk, J. Ethnopharmacol, 102, 23-31 2005.

[20] Dalal S, Rana S, Sastry K, Kataria S. 2009. Wedelolactone as an Antibacterial Agent extracted from Eclipta alba, International Journal of Microbiology. 7(1).
[21] Roy.RK, Thakur.M, Dixit.VK, Hair growth promoting activity of Eclipta alba in male albino Rats.Arch Dermotol res.300, 357-364.2008.

[22] Synthesis and characterization of Silver nanoparticles from Erythina Indica Asian Journal of pharmaceutical and clinical research, Vol 7(2), 2014.

[23] E.N.Dubis, A.T. Dubis, J.W. Morzycki "Comparative analysis of plant cuticular waxes using HATRFTIR reflection technique. Journal of Molecular structure, 511512, 173-179, 1994.

[24] A.G. Devi prasad, J. Komal kumar, P. Sharanappa Fourier transform infrared spectroscopic study of rare and endangered medicinal plants Romanian J. Biophysics 21(3), 221-230, 2-11.

[25] B. Ramesh babu,S. Marutha mutha, A. Rajsekhar, N. Muthukumar and Palaniswamy Microbiologically influenced corrosion in dairy effluent. International Journal of environment science and technology 3(2), 159166, 2006.

[26] Ivanova N.V. KorolonN E.V. IR spectrum of cellulose J. Appl. Spec, 51, 847-851, 1989.

[27] Multi-scale structural and chemical analysis of sugarcane bagasse in the process of sequential acid-base pretreatment and ethanol production by Scheffersomyces shehatae and Saccharomyces cerevisiae Biotechnology for biofuels 7,63,2014.

[28] Bellamy L.J. Infrared spectra of complex molecules, chapmann Hall London 1975.

[29] FTIR Spectroscopic analysis of plant (CALOTROPIS GIGANTEA) J. BIOPHYS., Vol. 17, No. 4, P. 269-276, BUCHAREST, 2007.

[30] Synthesis and optical characterization of amphorphous carbon nitride thin films by hot filaments assisted VACCUM 69(2003), 495-500.

[31]Hammer P, Baker MA, Lenardi C, Gissler W. J. Vac Sci A1997;15(1):107.

[32] Identification of American ginseng from different regions using FT-IR and two-dimensional correlation IR spectroscopy, Vibrational Spectroscopy, Volume 36, Issue 2, 6 December 2004, Pages 227-232.

[33] Barira Islam, Shahper N. Khan, Irfanul Haque, M. Alam, M. Mushfiq and Asad U. Khan1, Journal of antimicrobial chemotherapy 62(4), 751-757, 2008.

[34]Analysis by Fourier transform infrared spectroscopy of John Stania cuticles and compressions from Triassic of cacheuta, Mendoza Argentina -JOSE ALEJANDRO JD. ANGELE Vol.(4), 2006.

[35] Environment friendly inhibitor for mild steel byAntemesia,Halodendron,JiallHuang, Huicang, QianweilejinglShao, International Journal of electro chemical science, 8 2013, 8592-8602. 